\title{
TRAINING EFFECT OF SPECIAL BASKETBALL EXERCISES
}

\author{
Viktor Koryahin ${ }^{1 \mathrm{ABCD}}$, Oksana Blavt ${ }^{1 \mathrm{ABCD}}$, Eduard Doroshenko ${ }^{2 \mathrm{ABCD}}$, \\ Volodymyr Prystynskyi ${ }^{3 A B C D}$, Volodymyr Stadnyk ${ }^{1 A B C D}$ \\ ${ }^{1}$ Lviv Polytechnic National University \\ ${ }^{2}$ Zaporizhia State Medical University \\ ${ }^{3}$ State Higher Educational Institution "Donbass State Pedagogical University" \\ Authors' Contribution: A - Study design; B - Data collection; C - Statistical analysis; D - Manuscript Preparation; E - Funds Collection
}

Corresponding Author: Oksana Blavt, E-mail: oksanablavt@ukr.net

Accepted for Publication: September 20, 2020

Published: September 25, 2020

DOI: 10.17309/tmfv.2020.3.02

\begin{abstract}
The study objective is to evaluate the immediate training effect under the influence of changes in the parameters of physical activity in special exercises on the basis of physiological changes in the body of basketball players.

Materials and methods. The study used empirical methods of measuring heart rate during competitions, pulmonary ventilation values, $\mathrm{O}_{2}$ consumption during physical work, $\mathrm{O}_{2}$-debt, "excess" $\mathrm{CO}_{2}$, methods of mathematical statistics.

Results. An empirical study has shown that the exercises used in the preparation of basketball players differ significantly in the nature of physiological action. The greatest physiological shifts in the body of basketball players determine the exercise, which is performed intensively or repeatedly with maximum intensity. The smallest physiological shifts were found when performing free throws.

Conclusions. The magnitude and orientation of the immediate training effect of special exercises in basketball depend on the combination of the effects of all the main indicators of physical activity - the type of exercises used, their intensity and duration, duration of rest, the number of repetitions.

Keywords: basketball, special exercises, immediate training effect, physiological changes.
\end{abstract}

\section{Introduction}

Problem statement. The increase in sports scores in basketball is driven by scientifically sound management of the training process (Fort-Vanmeerhaeghe, Montalvo, Latinjak, \& Unnithan, 2016). Effective management of the training process of training basketball players can be implemented if a number of key tasks are solved (Koryagin, Blavt, \& Grebinca, 2016). Understanding this determines the direction of research that is constantly being undertaken to improve the training of athletes in various sports, including basketball, for many years.

At the present level of basketball development, as competition in the international and domestic sports arenas is increasing, the skill requirements of the athlete are increasing (Asadi, Saez de Villarreal, \& Arazi, 2015). The problem of streamlining the structure of the training process in basketball requires analysis of the sports training system, research

(C) Viktor Koryahin, Oksana Blavt, Eduard Doroshenko, Volodymyr Prystynskyi, Volodymyr Stadnyk, 2020. and selection of training facilities, as well as management of athletes' fitness condition (Anastasiadis, 2006; GonzaloSkok, Sánchez-Sabaté, Izquierdo-Lupón, \& Sáez de Villar, 2019). All kinds of training tools should be combined as much as possible to provide integrated training (Tyshchenko, Hnatchuk, Pasichnyk, Bubela, \& Semeryak, 2018). More than ever, the challenge is to limit the mobilization of functional reserves and maximize their mobilization to demonstrate the highest level of sporting capabilities.

Streamlining the structure of the training process will solve the problem of improving the process of training basketball teams masters and managing their activities in responsible games. Therefore, the issue of comprehensive training for highly skilled basketball players determines the importance of research aimed at ensuring the effectiveness of the training process.

Analysis of recent research and publications. In today's sports science, a vast amount of objective knowledge has been accumulated concerning the selection of the most effective training tools and methods aimed at enhancing athletes' functionality (Ben Abdelkrim, Castagna, El Fazaa, \& El 
Ati, 2010; Hoare, 2000; Webster, Horne, Wheelans, \& Bell, 2009). It is believed that this process is based on knowledge of the demands placed on the body by certain sports (Bosco, Luhtanen, \& Komi, 1983; Gonzalo-Skok et al., 2017; Ingebrigtsen, Jeffreys, \& Rodahl, 2013). The most pressing issue is the definition of requirements for the physical and especially functional fitness of athletes in sports games (Kozina, Iermakov, Cretu, Kadutskaya, \& Sobyanin, 2017; Koryagin \& Blavt, 2018; Sallet, Perrier, Ferret, Vitelli, \& Baverel, 2005).

In the modern system of sports training, the functional training section occupies one of the leading places (Anastasiadis, 2006; Ben Abdelkrim, El Fazaa, \& El Ati, 2007; Khudolii, 2019). The literature has intensified the scientific search for alternative approaches to assessing the functional preparedness of basketball players as a basis for managing the training process (Asadi et al., 2015; Montgomery, Pyne, \& Minahan, 2010).

Nowadays in basketball, the question of evaluating the training effect of special exercises of basketball players is mainly solved on the basis of the experience and intuition of the coach. In finding new tools and methods to improve the training process of skilled basketball players, it is of paramount importance to establish the immediate training effect of special basketball exercises (Ramos, Rubio, Martínez, Esteban, \& Jiménez, 2010). It has been suggested (Ben Abdelkrim, El Fazaa, \& El Ati, 2007) that physiological indicators that are highly informative (Green, Hughson, Orr, \& Ranney, 1983).

The available scientific research, conclusions and recommendations are of great value for solving the problem of training high-end basketball players. Based on the current interpretation of sports training (Asadi et al., 2015; FortVanmeerhaeghe et al., 2016), the choice of methodology in the planning and planning process should be maximally considered, availability of evaluation of the training process as a basis for its management.

In the theory and practice of basketball, the issues of planning and managing the modern training process have not been sufficiently studied and do not have adequate scientific substantiation. In the modern scientific and practical literature there are no works that would systematically and comprehensively cover the theory, methodology and practice of establishing the immediate training effect of special exercises of basketball players.

Given that physical training affects all components of basketball players' training and in order to gain knowledge of their performance it is necessary to have information on the impact of specific exercises used in the training process (Marchenko \& Dykhanova, 2019; Matthew \& Delextrat, 2009).

Purpose of the research: on the basis of physiological changes in the body of basketball players, to evaluate the immediate training effect under the influence of changes in the parameters of physical activity in special exercises.

\section{Materials and methods}

The study of the heart rate during competitions was conducted by means of the method of continuous automatic registration using the multichannel system (Koryagin \& Blavt, 2019). This allowed determine the maximum mean pulse rate during the game, as well as the maximum pulse rate total during the game and during the recovery.

The level of pulmonary ventilation was determined by way of collecting expired air into Douglas bags with the sub- sequent measurement of the volume of the air contained in the bag using a laboratory gas meter (Beaver, Wasserman, \& Whipp, 1986).

The percent composition was determined by way of analyzing the samples using the gas analyzers Spirolit and METAMAX that are capable of recording the concentration of $\mathrm{O}_{2}$ and $\mathrm{CO}_{2}$ in expired air.

All the indicators of the heart rate, as well as the level of $\mathrm{O}_{2}$ consumption, total $\mathrm{O}_{2}$, the level of $\mathrm{CO}_{2}$ release and oxygen pulse rate were calculated according to the method described in the works (Volkov, 1986; Zankovets, 2016).

\section{Results}

Studies have shown that special exercises used in the preparation of basketball players differ significantly in the nature of physiological effects on the body (Tab. 1).

It was found that the smallest physiological shifts were detected when performing free throws. The average heart rate was $128 \pm 2.24 \mathrm{bpm}$. Oxygen consumption level $-31 \%$ of the maximum carbon dioxide value is $0.18 \pm 0.17 \mathrm{l} / \mathrm{min}$. When performing other special exercises with moderate intensity, the heart rate is in the range of 140-150 beats per minute (in tall players within the range of 160 beats per minute), the level of oxygen consumption varies from 53.7 to $55.1 \%$ of the maximum value $(2.3 \mathrm{l} / \mathrm{min}$ on average), carbon dioxide evolution reaches $0.5 \mathrm{l} / \mathrm{min}$, pulmonary ventilation $45 \mathrm{l} / \mathrm{min}$.

The training effect of these exercises is predominantly aerobic. Physiological indicators, when performed by basketball players special exercises, belong to different ranges of training loads. The results of the studies that led to these conclusions are presented in Table 1.

The greatest physiological shifts in the body of the basketball players cause exercises that are performed in an intense or repeated mode with the maximum intensity and duration of each repetition of the exercise from $20-30 \mathrm{~s}$ to $2 \mathrm{~min}$.

The amount of oxygen consumption when performing such exercises reaches the maximum possible values of oxygen debt - increases to 10 liters.

Somewhat less pronounced physiological shifts are observed when performing game exercises (1x1 with the ball and without the ball, $2 \times 2,3 \times 3,5 \times 5$ on one shield). Here, the oxygen consumption is 65.2 to $82.4 \%$ of the maximum, the average heart rate is $172-187.5 \mathrm{bpm}$. The value of the oxygen debt is in the range from 5.8 to $7.2 \mathrm{l}$, carbon dioxide emission is $0.67-0.89 \mathrm{l} / \mathrm{min}$. These exercises are characterized by a complex effect on the body of athletes, that is, they contribute to the development of speed-power qualities and endurance.

When performing short-term exercises of 5-15 duration with an intensive or repeated method, the value of physiological shifts is negligible: the level of oxygen consumption was $68.1 \%$ of the maximum value. These exercises are characterized by the highest rate of formation of alactate oxygen debt $-68.5 \pm 17.5 \mathrm{ml} / \mathrm{min}$.

As can be seen from the results in the table, performing the same exercise with different combinations of physical activity indicators can cause different physiological shifts in the body.

Thus, it was found that the physiological indicators, which can serve to evaluate the immediate training effect of the exercises, have different informativeness. With the change of physical activity parameters, each indicator changes in a specific way. These changes occur until it reaches the limit 
Table 1. The value of physiological indicators when basketball players perform special exercises in various ranges of training loads

\begin{tabular}{|c|c|c|c|c|c|c|c|c|c|}
\hline $\begin{array}{l}\text { The focus of the } \\
\text { trainer }\end{array}$ & $\begin{array}{c}{\text { Level } \mathrm{O}_{2}} \\
\text { consumption } \\
1 / \mathrm{min}\end{array}$ & $\begin{array}{c}\text { Alactate } \\
\mathrm{O}_{2} \text {-debt, } \\
1\end{array}$ & $\begin{array}{c}\text { Lactate } \\
\mathrm{O}_{2} \text {-debt, } 1\end{array}$ & $\begin{array}{c}\text { Total } \mathrm{O}_{2-}^{-} \\
\text {debt, } 1\end{array}$ & $\begin{array}{c}\text { "Non- } \\
\text { metabolic } \\
\text { surplus" } \\
\mathrm{CO}_{2}, 1 / \mathrm{min} \\
\end{array}$ & $\begin{array}{c}\text { Level of } \\
\text { pulmonary } \\
\text { ventilation, } \\
\text { 1/min } \\
\end{array}$ & $\begin{array}{c}\text { Heart } \\
\text { rate, bpm }\end{array}$ & $\begin{array}{c}\text { Pulse } \\
\text { amount of } \\
\text { recovery, } \\
\text { beats } \\
\end{array}$ & $\begin{array}{c}\text { Average } \\
\text { heart } \\
\text { rate } \\
\text { bpm } \\
\end{array}$ \\
\hline Mostly aerobic & $\begin{array}{c}0.9-2.3 \\
1.6\end{array}$ & $\begin{array}{c}0.5-1.5 \\
0.75\end{array}$ & $\begin{array}{c}1.3-3.3 \\
2.3\end{array}$ & $\begin{array}{c}1.8-4.8 \\
3.2\end{array}$ & $\begin{array}{c}0.14-0.5 \\
0.32\end{array}$ & $\begin{array}{c}16-45 \\
20\end{array}$ & $\begin{array}{c}120-160 \\
140\end{array}$ & $\begin{array}{c}300-900 \\
600\end{array}$ & $\begin{array}{c}50-90 \\
70\end{array}$ \\
\hline $\begin{array}{l}\text { Mixed aerobic- } \\
\text { anaerobic }\end{array}$ & $\begin{array}{c}2.3-3.6 \\
2.95\end{array}$ & $\begin{array}{c}1.5-2.0 \\
1.75\end{array}$ & $\begin{array}{c}3.3-6.0 \\
4.65\end{array}$ & $\begin{array}{c}4.8-7.5 \\
6.15\end{array}$ & $\begin{array}{c}0.5-1.2 \\
0.85\end{array}$ & $\begin{array}{c}45-80 \\
62\end{array}$ & $\begin{array}{c}100-190 \\
175\end{array}$ & $\begin{array}{c}900-1900 \\
1400\end{array}$ & $\begin{array}{c}90-115 \\
102\end{array}$ \\
\hline Anaerobic glycolytic & $\begin{array}{c}3.6-4.3 \\
3.95\end{array}$ & $\begin{array}{c}2.0-2.6 \\
2.3\end{array}$ & $\begin{array}{c}6.0-6.8 \\
6.4\end{array}$ & $\begin{array}{c}7.5-9.5 \\
8.5\end{array}$ & $\begin{array}{c}1.2-1.8 \\
1.5\end{array}$ & $\begin{array}{c}80-140 \\
110\end{array}$ & $\begin{array}{c}180-190 \\
185\end{array}$ & $\begin{array}{c}1900-2300 \\
2115\end{array}$ & $\begin{array}{c}90-110 \\
100\end{array}$ \\
\hline Anaerobic alactate & $\begin{array}{c}2.3-3.1 \\
2.7\end{array}$ & $\begin{array}{c}1.3-1.9 \\
1.6\end{array}$ & $\begin{array}{c}2.3-4.4 \\
3.35\end{array}$ & $\begin{array}{c}5.1-6.2 \\
5.65\end{array}$ & $\begin{array}{c}0.35-0.8 \\
0.55\end{array}$ & $\begin{array}{c}50-75 \\
62\end{array}$ & $\begin{array}{c}170-190 \\
180\end{array}$ & $\begin{array}{c}730-1500 \\
1100\end{array}$ & $\begin{array}{c}94-103 \\
98.5\end{array}$ \\
\hline
\end{tabular}

values above which it becomes insensitive to the increasing impact of the load.

\section{Duscussion}

The basis of our study is based on the study of the immediate training effect of special exercises basketball players on the nature of physiological action on the body of athletes, as the basis for effective planning of the training process. The results of the empirical study complement the ideas of managing the training process based on the control of the impact of the means used in the training of qualified athletes (Fort-Vanmeerhaeghe et al., 2016; Gonzalo-Skok, Tous-Fajardo, Valero-Campo, Berzosa, Bataller, Arjol-Serrano, \& Mendez-Villanueva, 2017).

Better to understand the data obtained changes in the physiological functions of basketball players in the course of performing special exercises, allows their interpretation. The results of the study of physiological shifts in the body of basketball players in the performance of special exercises were consistent with the information that the parameters of physiological changes are correlated with the influence of different exercises (Cormery, 2008; Robert, McGown, Fisher, Dalsky, \& Robinson, 2017; Sallet, Perrier, Ferret, Vitelli, \& Baverel, 2005). Therefore, this allows them to be correlated by changing the parameters of the exercises (McArdle, Katch, \& Katch, 1991; Koryagin \& Blavt, 2018).

Considering that, based on the study of the immediate training effects of special exercises of basketball players, it is possible to systematize the exercises used in the training process of basketball players, the conducted research integrates the existing ideas in this direction. Therefore, information on improving the training system for skilled basketball players has been supplemented (Asadi et al., 2015; Fort-Vanmeerhaeghe et al., 2016; Gonzalo-Skok et al., 2019).

The obtained results expand and supplement the data on the effectiveness of the use of scientifically-based planning in the training of highly skilled basketball players, which involves the management of sports uniforms, the search for new rational means of special training (Aiken, Fairbrother, \& Post, 2012; Kozina et al., 2017; Scanlan, Fox, Borges, Tucker, \& Dalbo, 2018).

The researchers note the potential of using information on the impact of special exercises on the effectiveness of the training process in sports games in general (Backman \& Danielson, 2011; Ciuti, Marcello, Macis, Onnis, Solinas, \& Lai, 2009; Ingebrigtsen, Jeffreys, \& Rodahl, 2013). Thus, the study provides a further understanding of the factors that influence the effectiveness of training activities in training players. We have expanded the available data on the use of physiological control in the planning of the training process. Proper planning of the training process with the use of the data obtained from the study will allow rational use of training time, reaching a high level of basketball players.

The obtained results extend and supplement the data that increase of efficiency of a training process is possible on the basis of deep analysis of influence of physical activity on an organism of athletes (Karpowicz \& Karpowicz, 2013; Bosco et al., 1983; Robert et al., 2017).

The study results complement the information on pedagogical control of basketball players' training activities, which is the basis for appropriate regulation of planning and management of training of highly qualified basketball players to ensure its effectiveness (Asadi et al., 2015; Erčulj, Blas, \& Bračič, 2010; Vaquera, Santiago, Villa José, Morante, \& García-Tormo, 2015).

\section{Conclusions}

The first step in the creation of an effective system for managing the training process of basketball players is to establish an immediate training effect of special exercises. The most acceptable in assessing the immediate training effect of exercise may be physiological indicators that are highly informative.

Exercises used in the preparation of basketball players differ significantly in the nature of physiological effects. The magnitude and direction of the immediate training effect of special exercises in basketball depend on the combination of the effects of all the main indicators of physical activity - the type of exercises used, their intensity and duration of the amount of rest breaks, the number of repetitions.

The practical implementation of the formulated provisions will allow coaches and athletes to rationally and effectively build a multi-year process aimed at training skilled basketball players.

\section{Conflict of interest}

The authors state no conflict of interest.

\section{References}

Aiken, C.A., Fairbrother, J.T., \& Post, P.G. (2012). The Effects of Self-Controlled Video Feedback on the Learning of a 
Basketball Set Shot. Frontiers in Psychology, 3, 338. https://doi.org/10.3389/fpsyg.2012.00338

Anastasiadis, M. (2006). The Basketball Training. Athens: IN. Elvekalt EPE.

Asadi, A., Saez de Villarreal, E., \& Arazi, H. (2015). The effects of plyometric type neuromuscular training on postural control performance of male team basketball players. Journal of Strength and Conditioning Research, 29(7), 18701875. https://doi.org/10.1519/JSC.0000000000000832

Backman, L.J., \& Danielson, P. (2011). Low range of ankle dorsiflexion predisposes for patellar tendinopathy in junior elite basketball players: A 1-year prospective study. American Journal of Sports Medicine, 39(12), 2626-2633. https://doi.org/10.1177/0363546511420552

Beaver, W.L., Wasserman, K., \& Whipp, B.J. (1986). A new method for detecting anaerobic threshold by gas exchange. J. Appl. Physiol., 60, 2020-2027.

Ben Abdelkrim, N., Castagna, C., El Fazaa, S., \& El Ati, J. (2010). The effect of players' standard and tactical strategy on game demands in men's basketball. Journal Strength Cond Res, 24, 2652-62. https://doi.org/10.1519/JSC.0b013e3181e2e0a3

Ben Abdelkrim, N., El Fazaa, S., \& El Ati, J. (2007). Timemotion analysis and physiological data of elite under-19year old basketball players during competition. British Journal Sports Medicine, 41, 69-75. https://doi.org/10.1136/bjsm.2006.032318

Bosco, C., Luhtanen, P., \& Komi, P.V. (1983). Simple method for measurement of mechanical power in jumping. Eur $\mathrm{J}$ Appl Physiol, 50, 273-82.

Ciuti, C., Marcello, C., Macis, A., Onnis, E., Solinas, R., \& Lai, C. (2009). Improved aerobic power by detraining in basketball players mainly trained for strength. Journal Sports Medicine, Training and Rehabilitation, 6(4), 325335. https://doi.org/10.1080/15438629609512063

Cormery, B. (2008). Rule change incidence on physiological characteristics of elite basketball players: A 10-year-period investigation. British Journal of Sports Medicine, 42(1), 2530. https://dx.doi.org/10.1136/bjsm.2006.033316

Erčulj, F., Blas, M., \& Bračič, M. (2010). Physical demands on young elite European female basketball players with special reference to speed, agility, explosivestrength, and take-off power. J Strength Cond Res, 24, 2970-2978. https://doi.org/10.1519/JSC.0b013e3181e38107

Fort-Vanmeerhaeghe, A., Montalvo, A., Latinjak, A., \& Unnithan, V. (2016). Physical Characteristics of Elite Adolescent Female Basketball Players and Their Relationship to Match Performance. Journal of Human Kinetics, 53, 167-178. https://doi.org/10.1515/hukin-2016-0020

Gonzalo-Skok, O., Sánchez-Sabaté, J., Izquierdo-Lupón, L., \& Sáez de Villarreal, E. (2019). Influence of force-vector and force application plyometric training in young elite basketball players. European Journal of Sport Science, 19(3), 305-314. https://doi.org/10.1080/17461391.2018.1502357

Gonzalo-Skok, O., Tous-Fajardo, J., Valero-Campo, C., Berzosa, C., Bataller, A.V., Arjol-Serrano, J.L., \& MendezVillanueva, A. (2017). Eccentric overload training in team-sports functional performance: Constant bilateral vertical vs. Variable unilateral multidirectional movements. International Journal of Sports Physiology and Performance, 12(7), 951-958.

https://doi.org/10.1123/ijspp.2016-0251

Green, H.J., Hughson, R.L., Orr, G.W., \& Ranney, D.A. (1983). Anaerobic threshold, blood lactate, and muscle metabolites in progressive exercise. J. Appl. Physiol, 54, 1032-1038.

Hoare, D.G. (2000). Predicting success in junior elite basketball players-the contribution of anthropometic and physiological attributes. Journal Sci Med Sport, 3(4), 391405. https://doi.org/10.1016/s1440-2440 (00) 80006-7

Ingebrigtsen, J., Jeffreys, I., \& Rodahl, S. (2013). Physical characteristics and abilities of junior elite male and female handball players. J Strength Cond Res, 27(2), 302-309. https://doi.org/10.1519/JSC.0b013e318254899f

Karpowicz, K., \& Karpowicz, M. (2013). Structure of motor skills in young athletes. Hum Mov, 14(3), 221-228. https://doi.org/10.2478/humo-2013-0027

Khudolii, O. (2019). Research Program: Modeling of Young Gymnasts' Training Process. Teoriâ ta Metodika Fizičnogo Vihovannâ, 19(4), 168-178. https://doi.org/10.17309/tmfv.2019.4.02

Koryagin, V., \& Blavt, O. (2019). Innovative test control technologies in physical education and sports: a monograph. Lviv, Ukraine: Lviv Polytechnic Publishing House, 236.

Koryagin, V., Blavt, O., \& Grebinca, G. (2016). Optimization of the technical training system. Journal of Physical Education and Sport, 16(2), 1029-1030. https://doi.org/10.7752/jpes.2016.s2163

Koryagin, V., \& Blavt, O. (2018). The physiological evaluation of sports activities of basketball players. Physiological journal, 64(5), 41-46. https://doi.org/10.15407/fz64.05.041

Kozina, Z., Iermakov, S., Cretu, M., Kadutskaya, L., \& Sobyanin, F. (2017). Physiological and subjective indicators of reaction to physical load of female basketball players with different game roles. Journal of Physical Education and Sport, 17(1), 378-382. https://doi.org/10.7752/jpes.2017.01056

Marchenko, S., \& Dykhanova, A. (2019). Motor Abilities: Peculiarities of Effects of Volleyball Training on Coordination Preparedness of Girls Aged 15. Teoriâ ta Metodika Fizičnogo Vihovannâ, 19(1), 23-28. https://doi.org/10.17309/tmfv.2019.1.03

McArdle, W., Katch, F., \& Katch, V. (1991). Exercise physiology: energy, nutrition and human performance. Lea and Fabiger. Philadelphia. London.

Montgomery, P.G., Pyne, D.B., \& Minahan, C.L. (2010). The physical and physiological demands of basketball training and competition. International Journal of Sports Physiology and Performance, 5, 75-86. https://doi.org/10.1123/ijspp.5.1.75

Matthew, D., \& Delextrat, A. (2009). Heart rate, blood lactate concentration, and time-motion analysis of female basketball players during competition. J Sports Sci, 27, 813-821. https://doi.org/10.1080/02640410902926420

Robert, K.C., McGown, C.M., Fisher, A.G., Dalsky, G.P., \& Robinson, K.B.S. (2017). Physiological Effects of Power Volleyball. The Physician and Sportsmedicine, 10(2), 93-97. https://doi.org/10.1080/00913847.1982.11947167

Ramos, R., Rubio, J., Martínez, F., Esteban, P., \& Jiménez, J. (2010). Physiological, podological and somatometric 
Koryahin, V., Blavt, O., Doroshenko, E., Prystynskyi, V., \& Stadnyk, V. (2020). Training Effect of Special Basketball Exercises

characteristics of professional basketball player. Archivos de Medicina del Deporte, 27(136), 84-94.

Sallet, P., Perrier, D., Ferret, J.M., Vitelli, V., \& Baverel, G. (2005). Physiological differences in professional basketball players as a function of playing position and level of play. Journal Sport Med Phys Fit, 45, 291-295.

Scanlan, A.T., Fox, J.L., Borges, N.R., Tucker, P.S., \& Dalbo, V.J. (2018). Temporal changes in physiological and performance responses across game-specific simulated basketball activity. Journal of Sport and Health Science, 7(2), 176-182. https://doi.org/10.1016/j.jshs.2016.05.002

Tyshchenko, V., Hnatchuk, Ya., Pasichnyk, V., Bubela, O.O., \& Semeryak, Z. (2018). Factor analysis of indicators of physical and functional preparation of basketball players.
Journal of Physical Education and Sport, 18(s4), 269, 18391844. https://doi.org/10.7752/jpes.2018.s4269

Vaquera, A., Santiago, S., Villa José, G., Morante, J.C., \& GarcíaTormo, V. (2015). Anthropometric Characteristics of Spanish Professional Basketball Players. Journal of Human Kinetics, 46, 99-106. https://doi.org/10.1515/hukin-2015-0038

Webster, A.L., Horne, L., Wheelans, L. \& Bell, G.J. (2009). Physical and physiological characteristics of elite ringette players. Sports Medicine, Training and Rehabilitation, 9(1), 25-40. https://doi.org/10.1080/15438629909512542

Volkov, N.I. (1986). Biochemical factors of sports performance. M.: FiS. (in Russian)

Zankovets, V. (2016). Testing Encyclopedia. M.: Sport. (in Russian)

\title{
ТРЕНУВАЛЬНИЙ ЕФЕКТ СПЕЦІАЛЬНИХ ВПРАВ БАСКЕТБОЛІСТІВ
}

\author{
Віктор Корягін $^{1 \mathrm{ABCD}}$, Оксана Блавт ${ }^{1 \mathrm{ABCD}}$, Едуард Дорошенко ${ }^{2 \mathrm{ABCD}}$, Володимир \\ Пристинський ${ }^{3 \mathrm{ABCD}}$, Володимир Стадник ${ }^{1 \mathrm{ABCD}}$ \\ ${ }^{1}$ Національний університет «Львівська політехніка» \\ ²Запорізький державний медичний університет \\ ${ }^{3}$ ДВНЗ «Донбаський державний педагогічний університет»
}

Авторський вклад: А - дизайн дослідження; В - збір даних; C - статаналіз; D - підготовка рукопису; Е - збір коштів

Реферат. Стаття: 5 с., 1 табл., 36 джерел.

Мета дослідження - на основі фізіологічних змін в організмі баскетболістів здійснити оцінку термінового тренувального ефекту під впливом змін параметрів фізичного навантаження у спеціальних вправах.

Матеріали та методи. У дослідженні було використано емпіричні методи вимірювання частоти серцевих скорочень під час змагань, величини легеневої вентиляції, $\mathrm{O}_{2}$-споживання під час фізичної роботи, $\mathrm{O}_{2}$-боргу, «надлишку» виділення $\mathrm{CO}_{2}$, методи математичної статистики.

Результати. Проведене емпіричне дослідження показало, що вправи, які застосовуються при підготовці баскетболістів, істотно розрізняються за характером фізіологічної дії. Найбільші фізіологічні зрушення в організмі баскетболістів зумовлюють вправи, що виконуються в інтенсивному або повторному режимі з максимальною інтенсивністю. Найменші фізіологічні зрушення виявлені при виконанні штрафних кидків.

Висновки. Величина і спрямованість термінового тренувального ефекту спеціальних вправ в баскетболі залежать від поєднання впливів всіх основних показників фізичного навантаження - виду застосовуваних вправ, їхньої інтенсивності та тривалості, тривалості відпочинку, числа повторень.

Ключові слова: баскетбол, спеціальні вправи, терміновий тренувальний ефект, фізіологічні зміни.

\section{Information about the authors:}

Koryahin Viktor: koryahinv@meta.ua; https://orcid.org/0000-0003-1472-4846; Department of Physical Education, Lviv Polytechnic National University, Bandera St, 12, Lviv, 79013, Ukraine.

Blavt Oksana: oksanablavt@ukr.net; https://orcid.org/0000-0001-5526-9339; Department of Physical Education, Lviv Polytechnic National University, Bandera St, 12, Lviv, 79013, Ukraine.

Prystynskyi Volodymyr: v.prystynskyi@hotmail.com; https://orcid.org/0000-0003-1681-3543; Department of Theoretical, Methodological Foundations of Physical Education and Rehabilitation, State Higher Educational Institution "Donbass State Pedagogical University", Batiuka St, 19, Sloviansk, 84116, Ukraine.

Doroshenko Eduard : doroe@ukr.net; https://orcid.org/0000-0001-7624-531X; Department of Physical Rehabilitation, Sports Medicine, Physical Education and Health, Zaporizhzhia State Medical University, Mayakovsky Av, 26, Zaporizhzhia, 69035, Ukraine. Stadnyk Volodymyr: vova121212131313@ukr.net; https://orcid.org/0000-0002-2864-4794; Lviv Polytechnic National University, Bandera St, 12, Lviv, 79013, Ukraine.

Cite this article as: Koryahin, V., Blavt, O., Doroshenko, E., Prystynskyi, V., \& Stadnyk, V. (2020). Training Effect of Special Basketball Exercises. Teoriâ ta Metodika Fizičnogo Vihovannâ, 20(3), 137-141. https://doi.org/10.17309/tmfv.2020.3.02

Received: 3.05.2020. Accepted: 20.09.2020. Published: 25.09.2020

This work is licensed under a Creative Commons Attribution 4.0 International License (http://creativecommons.org/licenses/by/4.0). 